\title{
esmt
}

September 15, 2009
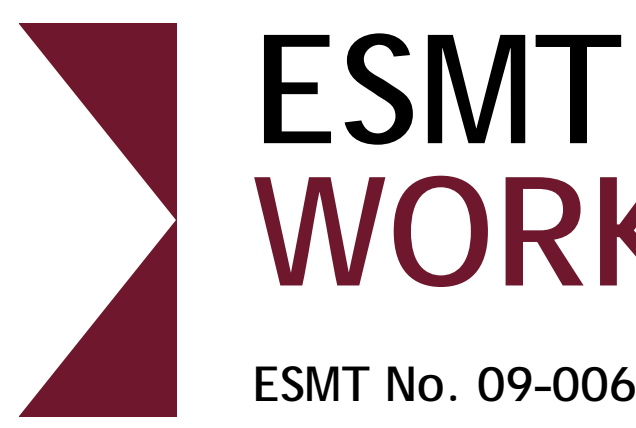

WORKING PAPER

ESMT No. 09-006

\section{ISO 9000: New Form of Protectionism or Common Language in International Trade?}

Joseph A. Clougherty, University of Illinois at Urbana-Champaign Michat Grajek, ESMT 


\title{
Abstract
}

\section{ISO 9000: New Form of Protectionism or Common Language in International Trade? ${ }^{1}$}

\author{
Author(s)*: Joseph A. Clougherty, University of Illinois at Urbana-Champaign \\ Michat Grajek, ESMT
}

International standards have the potential to both promote and hinder international trade. Yet empirical scholarship on the standards-trade relationship has been held up due to some methodological challenges: measurement problems, varied effects, and endogeneity concerns. We are able to surmount these challenges while considering the impact of one particular standard on the country-pair trade flows between 91 nations over the 1995-2005 period. To deal with these challenges, we measure the degree of standardization via the penetration of ISO 9000 in individual nations, allow ISO diffusion to manifest via multiple (quality-signaling, information/compliance-cost, and common-language) effects, and use instrumental variable and panel data techniques to overcome endogeneity concerns. We find strong evidence in support of ISO 9000 involving a common-language effect that enhances country-pair trade; yet, the evidence is more mixed with regard to the quality-signaling and information/compliance-cost effects. While we find ISO-rich nations (most notably European) to clearly benefit from the worldwide diffusion of standardization, ISO 9000 represents a de facto trade barrier for nations (e.g., the US and Mexico) lagging behind in terms of adoption.

Keywords: international trade, standards, technical trade barriers, iso 9000, networks

JEL Classification: F13, L15, C51

Financial support from the German Federal Ministry of Education and Research is gratefully acknowledged (project 01AK702A). We would also like to thank Susanne Prantl, Lars-Hendrik Röller, Oz Shy, Christian Wey, and Eric van Wincoop, as well as participants of the EARIE conferences in Porto and Ljubljana, the EEA congress in Amsterdam, and the ETSG conference in Athens for helpful comments and discussions on earlier drafts of the paper. Claudia Baldermann and Jennifer Rontganger provided excellent research assistance. All remaining errors, however, are our own.

* Contact: Michat Grajek; ESMT, Schlossplatz 1, 10178 Berlin, Germany;

Tel: +49 (0)30 212 31-1047, Email: grajek@esmt.org. 
Many trade scholars (e.g., Sam Laird and Alexander Yeats 1990; Alessandra Casella 1996; Alan V. Deardorff and Robert M. Stern 1998; Ernest H. Preeg 1998; Richard Baldwin 2000) have observed that the substantial decrease in trade barriers over the last few decades has led to technical trade barriers (TTBs) - such as standards - becoming increasingly important determinants of international trade flows. Yet unlike tariffs and common non tariff barriers (NTBs), standards have the potential to not only decrease but also expand trade. While international standards have been found to promote trade more than national standards (e.g., Knut Blind 2001; Johannes Moenius 2004; Witold Czubala, Ben Shepherd and John S. Wilson 2007; Shepherd 2007) ${ }^{1}$, they still have the power to be protectionist when consumers and large buyer groups require production according to these standards and compliance costs are relatively significant (Johannes Moenius 2006). Despite the recognized importance of the subject, there is almost universal agreement that we lack sufficient empirical evidence concerning the relationship between standards and trade (e.g., Carmen Matutes and Pierre Regibeau 1996; Keith E. Maskus, John S. Wilson and Tsunehiro Otsuki 2000; Knut Blind 2004; Moenius 2006). In this vein, Maskus, Wilson and Otsuki (2000: 45) state that "it is important to obtain as much information as possible about the quantitative implications of standards ... [for] ... trade prospects". Yet three challenges in particular have held back empirical scholarship on the international trade implications of standardization.

First, measurability difficulties represent a significant challenge that has curtailed efforts to successfully capture the impact of standards on trade. Deardorff and Stern (1998) note that standardization is one of the hardest NTBs imaginable to quantify - a lament echoed by many other studies (e.g., Laird and Yeats 1990; Maskus, Wilson and Otsuki 2000; Blind 2004; Shepherd 2007). In short, the evidence on standards does not necessarily come in a form that

\footnotetext{
${ }^{1}$ Peter Swann, Paul Temple and Mark Shurmer (1996) represent an exception in that they found national standards to promote trade more than international standards.
} 
facilitates quantitative analysis. As a result, empiricists have tended to construct a simple count of the number standards - or the number of documents - in existence in order to capture the applicable degree of standardization in a nation or sector. Yet this inventory approach gives equal weight to all existing standards, and thus cannot differentiate between the effectiveness and significance of different standards (Laird and Yeats 1990; Swann, Temple and Shurmer 1996). Unfortunately, the pre-existing empirical literature appears to lack a natural and straightforward means to measure the intensity of standardization.

Second, the varied effects that standards potentially have make it difficult to identify the particular channels via which standards impact trade, hence empirical scholarship has often tended to elicit net effects. For one, the diffusion of standards can increase the competitiveness of a home-nation's products - signaling quality and safety - therefore leading to enhanced exports (Swann, Temple and Shurmer 1996; Blind 2001, 2004; Mattias Ganslandt and James R. Markusen 2001). Further, the existence of standards in a host-nation can be favorable to trade as it provides crucial information to exporting firms on how to adapt a product for a particular market (Moenius 2004, 2006). Yet, host-nation standards may also be used in a protectionist manner to raise the costs of foreign competition (Anette Boom 1995; Neil Gandal and Oz Shy 2001; Ganslandt and Markusen 2001). Such protectionist elements can be particularly strong when foreign firms face high adoption costs due in part to their having little influence on the standardization process (Maskus, Wilson and Otsuki 2000; Blind 2001). In addition, Danièle Bénézech et al. (2001) point out that standards also involve common-language elements that potentially facilitate exchanges between firms from different countries. For instance, Blind (2001) notes that corresponding-knowledge and absorptive-capacity in a country-pair yields efficient use of standards; and Moenius (2004) holds that bilaterally shared standards greatly enhance trade. In light of these multiple potential effects, it is no surprise that Maskus, Otsuki and 
Wilson (2004) observe a mixed empirical record with standards sometimes enhancing and sometimes impeding trade.

Third, endogeneity represents an additional challenge to the empirical literature on standards and trade, as the causal inferences concerning the impact of standardization may be inconsistent and biased. The potential for simultaneity between exports and trade barriers has been recognized for some time (e.g., James Harrigan 1993; Daniel Trefler 1993; Jong-Wa Lee and Phillip Swagel 1997), yet efforts to deal with endogeneity are a more recent phenomenon (e.g., Scott L. Baier and Jeffrey H. Bergstrand 2002, 2007; Chris Magee 2003). In particular, not only might international trade benefit from harmonization of standards due to decreasing trade barriers, but the standardization process might also in turn be determined by foreign trade intensity, as this indicates an economy's openness (Casella 1996; Knut Blind 2002). In support of this conjecture, Moenius (2004) employs Granger test and finds evidence of two-way causality between standards and trade volumes. As a consequence, empirical models of international trade using standardization as an explanatory variable may suffer from endogeneity bias. Thus, endogeneity issues have also held back efforts to successfully capture in a consistent manner the impact of standards on international trade.

With the above issues in mind, we empirically investigate the impact of one particular international standard - ISO 9000 - on bilateral trade flows using a panel of cross-section timeseries data at five-year intervals from 1995-2005 for 91 nations. The ISO 9000 certification system for quality management represents the most successful standard - close to 777,000 worldwide certificates by 2005 - implanted by the International Organization for Standardization: a post-World War II Geneva-based international institution charged with developing standards to enhance global trade. The merits of studying ISO 9000's impact on trade reside beyond this being - by far - the most successful international standard in existence, as we can employ diffusion 
data (ISO 2002, 2006) to capture the degree to which the standard is adopted in a particular nation. We are able to move then beyond the customary inventory approach to measuring standardization, and instead consider the penetration of this seminal standard in a national environment. Furthermore, we can use home-nation and host-nation diffusion rates - and the interaction of the two - in order to identify the different channels via which standardization affects trade. Finally, we attempt to overcome the limitation of 'potential endogeneity' by employing panel-data procedures and instrumental variable (IV) techniques. In particular, we conduct estimations using country-pair fixed effects and multilateral resistance terms, as well as estimations using ISO 14000 - a sister standard involving environmental procedures - as a potentially powerful and valid instrument.

In addition to the above core methodological issues which we attempt to surmount, we will also consider the issue as to whether the EU potentially used ISO 9000 in a protectionist manner. The requirement of an EC Mark (a public safety standard based on ISO 9000) to gain access to European markets and the significant influence held by the EU in the International Organization for Standardization (where ISO 9000 was designed) suggest that ISO 9000 may indeed have been employed by the EU as a device to enhance intra-European trade at the expense of imports from non-European nations. In particular, the trade barrier aspects of ISO 9000 are potentially more severe for developing nations as they often lack the infrastructure to support implementation of the standard (Maskus, Wilson and Otsuki 2000) and in turn exhibit relatively slower diffusion of ISO standards (Magali A. Delmas 2002). Thus in line with the theoretical work by Gandal and Shy (2001), ISO 9000 may have been used to create a virtual standardization union. Accordingly, we will consider whether the worldwide diffusion of ISO 9000 has principally benefited European nations at the expense of non-European - particularly developing - nations. 
The rest of the paper is organized as follows in order to support our analysis. Section I provides relevant background on the ISO 9000 standard and the data employed in the study. Section II considers the different channels via which standards may impact international trade flows. Section III sets out the base gravity equation, discusses econometric issues, and presents initial empirical findings. Section IV considers whether the benefits and costs of worldwide ISO 9000 standardization are evenly distributed among nations. Section V concludes.

\section{Background on ISO 9000 Standard and Employed Data}

The main objective of the International Organization for Standardization is to harmonize worldwide standards in order to promote trade and thereby global welfare. To this end, ISO 9000 - as already noted - has been the most successful standard implanted by the International Organization for Standardization. The history of ISO 9000 started in 1987 with the publication of the ISO 9000 Quality Assurance Standards by a Technical Committee (TC 176) of the International Organization for Standardization. The standard spread to over 160 countries by the end of 2005, therefore solidifying its reputation as an international reference for quality requirements in business-to-business dealings (ISO 2002). Table 1 illustrates the rapid and successful worldwide penetration of this seminal standard by reporting the number of ISO 9000 certificates present in 2005 for each of the 91 countries from our sample.

ISO 9000 adoption is a firm-based (or better said, premise-based) decision; however, firms can seek certification only in their home countries. Each country has one governmentdesigned accrediting agency that certifies the competence of third party registrars to conduct ISO 9000 quality audits - registrars are also charged with the issuing of certificates (Shannon W.

Anderson, Daniel Daly and Marilyn F. Johnson 1995, 1999). In general, motivations behind the 
implementation of ISO 9000 could be divided into three main categories: i) compliance with government regulations, ii) ability to establish business relationships by meeting buyer requirements, and iii) internal efficiency gains. In fact, all the factors influencing managers to seek ISO 9000 certification - as identified by Anderson, Daly and Johnson (1999) in a comprehensive review of practitioner journals - fall into one of these three categories.

The ISO 9000 family of standards are often referred to as generic quality management standards - generic in the sense that they can be implemented by any organization regardless of its size, activity sector, or managerial/national culture. Quality management reflects what the organization does to enhance customer satisfaction by meeting buyer requirements and expectations (ISO 2002). Compliance with ISO 9000 indicates consistent use of documents and standardized procedures to produce a good or service. In other words, ISO 9000 certifies that a firm's products - for which a customer contracts - conform to specification.

In our analysis, we treat ISO 9000 as a uniform standard even though it consists of a series of nested standards which evolved over time. Firms originally chose between three core certificates (ISO 9001, ISO 9002, and ISO 9003) that differed in terms of the covered quality system elements. The nested nature of these standards allowed firms to accommodate differences in the scope of their operations. ${ }^{2}$ The 2000 edition of the ISO 9000 family replaced these three standards with a single standard labeled ISO 9001:2000. As supplementary standards, the 2000 edition included ISO 9000:2000, which describes fundamentals and specifies vocabulary for a quality management system, and ISO 9004:2000, which provides guidelines for performance improvements. Both of these standards (ISO 9000:2000 and ISO 9004:2000) were developed on the basis of previous ISO standards. Given that the core members of the ISO 9000 family were finally replaced by a single standard, the simplifying assumption of this paper treating ISO 9000

\footnotetext{
${ }^{2}$ See Anderson, Daly and Johnson $(1995,1999)$ for details.
} 
as a uniform standard seems justified, and has been practiced in the literature (e.g., Isin Guler, Mauro F. Guillén and John M. Macpherson 2002; Aseem Prakash and Matthew Potoski 2006, 2007; Ann Terlaak and Andrew King 2006).

Accordingly, data for our empirical analysis is compiled from the International Organization for Standardization (ISO 2002, 2006) as well as from other sources such as the UN's Comtrade and the World Bank's World Development Indicators. We construct a panel (for every five years) from 1995-2005 of the bilateral trade flows and standard gravity equation variables among 91 potential trading partners (an actual 7,346 country-pairs with usable data) ${ }^{3}$, and then match these data with ISO 9000 diffusion rates for the 91 nations over the same period: the respective national certification counts for ISO are reported in Table 1. We use five-year time intervals in order to tease out long-term effects rather than short-term adjustments - a common approach in the international trade literature (e.g., Jeffrey A. Frankel and Shang-Jin Wei 1997a; James E. Rauch and Victor Trindade 2002; Baier and Bergstrand 2007). In the time dimension, the sample is restricted to just three years $(1995,2000$ and 2005) due to availability of instruments. ${ }^{4}$ Yet in the cross-section dimension, the sample is fairly large: covering approximately $80 \%$ of worldwide trade, and $99 \%$ of worldwide ISO 9000 adoptions. An advantage of the wide sample is that less developed nations - where the trade barrier elements may manifest - are included; hence, the generality of our results will not suffer then from selection bias.

Table 2 lists all variables used in the estimations along with their definitions, sources, and descriptive statistics. Exports, GDP, population, and distance follow standard definitions used in

\footnotetext{
${ }^{3}$ Note that we define the country-pair as exporter-importer specific; for instance, US-Canada and Canada-US are two distinct country-pairs.

${ }^{4}$ ISO 14000 represents the main instrument for ISO 9000 - see the description in Section III.B - and this instrument is unfortunately not available prior to 1995 as the standard was initiated in 1995
} 
gravity models. For the sake of international comparability, the ISO 9000 variable is constructed in relation to a nation's population. ${ }^{5}$ The ISO 14000 variable is treated in the same way. The infrastructure index is a simple average of road density, air passengers per capita, and telephone lines per capita — all of which are likely to reduce home-nation and host-nation trade costs (Cèline Carrère 2006). Finally, the FTA variable is taken from Baier and Bergstrand (2007) and covers all free trade agreements worldwide until 2000.

The developers of ISO 9000 did indeed envision that "through world-wide acceptance and use, the ISO 9000 family of standards will provide an effective means for improving the performance of individual organizations and providing confidence to people and organizations that products (goods and services) will meet their expectations thereby enhancing trade, global prosperity and individual well-being" (ISO 2005: p.4). In line with this aim, some scholarship has proposed that the adoption of ISO 9000 certificates enhances international trade (e.g., John Hudson and Philip Jones 2003; Joseph A. Clougherty and Michał Grajek 2008). We now turn to how ISO 9000 - and international standards in general - may have varied effects on trade between nations.

\section{Varied Trade Effects of Standardization}

As noted in the introductory comments, standardization can affect international trade flows via a variety of channels. In order to begin to break down the net effect of standardization into composite effects, we will concentrate here on three particular channels: 1) an enhancedcompetitiveness effect captured by home-nation standardization; 2) a combined

\footnotetext{
${ }^{5}$ Because empirical gravity equations employ the logs of variables, we add 1 to the number of ISO 9000 certificates in a nation - before taking the logarithm of (ISO certificates / population) - in order to avoid losing observations when the number of certificates in one of the trading nations equals zero. Note also that the reported results are robust to using GDP as a denominator; however, population is less subject to endogeneity than is GDP.
} 
information/compliance-cost effect captured by host-nation standardization; 3) a commonlanguage effect captured by the interaction of home-nation and host-nation standardization.

First, diffusion of standards in a home-nation environment can yield a competitive advantage for national firms that augments exports. This enhanced competitiveness dynamic may be due to internal efficiency gains and quality improvements on the part of firms adopting standards (Swann, Temple and Shurmer 1996). For example, Anderson, Daly and Johnson (1999) report average annual savings of $\$ 200,000$ for a mid-sized US firm due to ISO certification. These internal gains would seemingly influence firms' general competitiveness and thereby influence trade flows. In light of the fact, however, that ISO certification also involves an implementation cost - Blind (2004) estimates it to be between $\$ 50,000$ and $\$ 250,000$ - it is no surprise that firms with good pre-existing quality systems may find ISO 9000 to generate internal losses due to the added costs, delays, and burdensome documents necessary for certification (Milé Terziovski Damien Power and Armik S. Sohal 2003).

Since internal firm benefits may likely be minimal, most scholarship keys upon external firm benefits as the principal dynamic via which standardization enhances the competitiveness of exports (Hudson and Jones, 2003). For instance, Blind (2004) notes that minimum quality standards - like ISO 9000 - can substantially reduce transaction and search costs. In particular, ISO 9000 not only proxies for conformance of the firm's product to its specification, but can also signal a firm's superior but unobserved attributes. In line with this argument, Terlaak and King (2006) find ISO certification to increase facility growth when buyers face multiple suppliers and the attributes of suppliers are intangible. Furthermore, Clougherty and Grajek (2008) find ISO certification to facilitate trade in developing nations where established institutional frameworks to detect quality-valuing firms are lacking. In short, ISO 9000 potentially offers a low-cost signal of a firm's commitment to quality that alleviates information asymmetries and transaction costs and 
can thus lead to enhanced exports when the standard is diffused widely in a home-nation environment.

Second, diffusion of standards in the host-nation environment can involve two countervailing effects - an information effect and a compliance-cost effect - that impact international trade flows (Moenius 2004, 2006). In terms of the information effect, the adoption of a standard by a nation represents a mechanism via which local knowledge is disseminated and more easily available to foreign firms, therefore providing information on the necessary criteria for selling in a national market (Swann, Temple and Shurmer 1996). This dynamic creates obvious export opportunities for foreign firms as transparency and clarity are enhanced and the cost of acquiring information regarding the host-nation environment is reduced. For example, the mass adoption of ISO 9000 in a target environment represents an efficient improvement for exporters when compared with a situation where each customer specifies unique quality-control requirements. In this vein, Anderson Daly and Johnson (1999) point out that the adoption of ISO by US auto manufacturers for supplier relations resulted in the elimination of three other quality standards.

However, the diffusion of standards in a host-nation environment can also hinder trade if this induces substantial compliance costs on the part of foreign producers (Moenius, 2006). In order to become certified, foreign producers must adapt manufacturing design, reorganize production systems, and comply with multiple certification and testing procedures (Paul Brenton, John Sheehy and Marc Vancauteren 2001). These compliance costs have been found to be substantial for middle- to smaller-sized firms (David Hanson 2005) and for firms hailing from developing nations (Maskus, Wilson and Otsuki 2000; Czubala, Shepherd and Wilson 2007). Thus bearing out Blind's (2001) observation that adaptation costs may be particularly high for those firms with no influence on the standardization process. Accordingly, the implantation of a 
standard in a host-country environment can aversely affect foreign producers by increasing their compliance costs, and hindering trade when these adaptation costs are substantial. In sum, adoption of the ISO 9000 standard in the host-nation environment involves two countervailing effects (a positive information effect and a negative compliance-cost effect); thus, the net-effect depends upon whether the trade-fostering elements outweigh the trade-hindering elements.

Third, standards have also been noted to have common-language properties that facilitate cross-firm communication. Blind (2001) points out that corresponding technical knowledge on both ends of a country-pair is essential to enhance the efficiency of communication and promote cross-border trade; i.e., the standard must be adopted in both the home and host nation in order to establish a common-language. Furthermore, a number of scholars (Steve Casper and Bob Hancké 1999; Sunil M. Dissanayaka et al. 2001; Clougherty and Grajek 2008) have argued that ISO 9000 involves such properties, as the certificate can establish a means to communicate the nature of internal production systems to buyers and provide a cross-organizational procedural language in business-to-business dealings. Bénézech et al. (2001: p. 1396) summarize this point when stating that "the ISO 9000 series can be viewed as a code, a language used by firms". The standardized documentation flow and organizational procedures within ISO certified firms naturally lowers information asymmetries between firms, which in turn leads to lower transaction and search costs in vertical relations. Yet to fully realize the benefits of ISO 9000, both contracting parties should have adopted (i.e., learned) it in the first place; hence, the appropriateness of the commonlanguage analogy. In short, the common-language properties of ISO 9000 can reduce the communication frictions endemic to trade relations between firms from different nations by allowing the ready communication of internal production systems.

This common-language dynamic has elements in line with the literature strand considering the role of networks in reducing the information costs associated with international 
trade (e.g. James E. Rauch 1999; Rauch and Trindade 2002). Rauch and Trindade (2002) note that via matching buyers and sellers in characteristics space, networks may involve a considerable quantitative impact on trade flows, since inadequate information about opportunities represents a substantial informal barrier to international trade. To the extent that ISO 9000 promotes a like-minded community with lower internal information and search costs, its role for international trade resembles the role of ethnic Chinese networks and the internet studied by Rauch and Trindade (2002) and Caroline L. Freund and Diana Weinhold (2004), respectively. Accordingly, our work partly follows through on Rauch's (1999) observation that the network/search view of international trade opens up space for greater consideration of the role played by contacts and relationships in determining the geographic distribution of economic activity. In our case, learning the common language of ISO 9000 could be viewed as an alternative to establishing vertical relations based on long-term interactions and a reputation for trust.

In sum, we consider the ability of ISO 9000 standards to impact international trade flows via three principal channels. First, diffusion of ISO 9000 standards in the home-nation can promote country-pair exports: an enhanced competitiveness effect. Second, diffusion of ISO 9000 in the host-nation can either promote or hinder country-pair exports: depending on whether the information effect outweighs the compliance-cost effect. Third, combined diffusion of ISO 9000 in both the home and host nation can promote country-pair exports: a common-language effect. In order to account for these different effects, we employ the number of ISO certificates relative to population to capture the standard's penetration in a nation, and then introduce these measures for exporting and importing countries (ISO adoption for the home-nation, host-nation, and interaction of home and host nations) into a country-pair export equation. The interaction term's 
identification of the common-language effect is very helpful, as otherwise common-language properties would manifest via the individual home-nation and host-nation ISO variables.

\section{Estimating the Trade Effects of ISO 9000}

\section{A. Model selection and estimation issues}

The standard empirical framework used to predict international trade flows is a gravity equation, which merely states that bilateral trade flows are proportional to the economic masses of the trading parties and inversely proportional to the distance - or more generally trade barriers - between them. Its attractiveness stems from a strong theoretical background and a long record of empirical studies yielding robust results. The empirical studies employing versions of the gravity equation began with the seminal contributions of Jan Tinbergen (1962) and Hans Linnemann (1966); and the theoretical foundations include James E. Anderson (1979), Bergstrand (1985), Elhanan Helpman and Paul Krugman (1985), Deardorf (1998) - and more recently Jonathan Eaton and Samuel Kortum (2002) and Anderson and Eric van Wincoop (2003).

To analyze the problem at hand, we allow ISO 9000 diffusion in both home and host nations to affect trade flows within a standard gravity equation set-up of the following fashion:

$$
\begin{aligned}
\ln \operatorname{Exp}_{i j t} & =\alpha+\beta_{1} \ln G D P_{i t}+\beta_{2} \ln G D P_{j t}+\beta_{3} P O P_{i t}+\beta_{4} P O P_{j t}+\gamma \ln \text { Distance }_{i j}+ \\
& +\delta_{1} \ln \left(I S O 9000_{i t}\right)+\delta_{2} \ln \left(I S O 9000_{j t}\right)+\delta_{3} \ln \left(I S O 9000_{i t}\right) \ln \left(\text { ISO9000 }_{j t}\right)+ \\
& +\phi_{1} \ln \operatorname{Infr}_{i t}+\phi_{2} \ln I n f r_{j t}+\lambda_{t}+\varepsilon_{i j t},
\end{aligned}
$$

where the subscripts $i, j$ and $t$ stand for home-nation, host-nation, and year respectively. In addition, note that a particular country-pair's economic mass and transportation costs are respectively captured by GDP and population (both home and host nation), and the distance measure. 
It also bears reiterating that ISO 9000 may affect international trade flows through different channels, hence three different ISO variables are inserted into the gravity equation. A positive coefficient estimate for home-nation ISO diffusion can indicate higher efficiency or better quality-signaling on the part of home-nation exporters. A negative (positive) coefficient estimate for host-nation ISO diffusion indicates that the compliance-cost (information) effect is relatively strong. Finally, a positive coefficient estimate for the interaction of home-nation and host-nation diffusion would indicate the presence of common-language properties regarding ISO 9000 adoption.

Our gravity equation also explicitly controls for a number of additional factors. First, we control for the impact of any time-specific effects - e.g., world income trends - in the data series with year dummies: employing time effects $-\lambda_{t}-$ is a standard practice in empirical models of international trade. Second, we account for a potentially heteroskedastic and autocorrelated error term $-\varepsilon_{i j t}-$ by using cluster-robust standard errors in the estimations: where clusters are defined as country-pairs. Third, we control for the impact of the physical infrastructure held by trading partners via home and host nation infrastructure indices, since physical infrastructure is likely to be positively correlated with soft infrastructure like ISO 9000. Neglecting such drivers of trade might bias the ISO 9000 coefficient estimates upward.

While the above properties describe well the estimation procedures for the base gravity equation model, a number of other econometric/modeling issues should be considered in order to generate robust causal inferences: 1) proper model selection for the standards/trade relationship; 2) fixed country-pair specific effects; 3) multilateral resistance terms. These three issues lead directly to three additional regression equation models that we will estimate in addition to the base gravity equation model. 
First, our base gravity equation follows the approach by Moenius (2004) for studying the standards/trade relationship by using GDP and population (for both home and host nations) and geographical distance as the core gravity variables. We, however, also include the infrastructure constructs for home and host nations in order to elicit more confident interpretations for our variables of principal concern: the ISO 9000 diffusion constructs. Yet, Maskus, Wilson and Otsuki (2000) critique the Moenius (2004) approach for omitting an indicator of joint membership in regional trade agreements: i.e., not controlling for FTA effects. Our base gravity equation does not control for the presence of existing FTAs, because we lack data for 2005 concerning the presence of FTAs. ${ }^{6}$ Nevertheless, it is important to follow through on the prescription by Maskus, Wilson and Otsuki (2000) concerning a robust and useful gravity equation to elicit the impact of standardization on trade. Accordingly, we estimate our base gravity equation while also including measures for regional trade agreements. Yet, the limitation of this approach is the omission of data points from 2005; thus, the panels for these estimations simply involve two years: 1995 and 2000.

Second, our base gravity equation does not explicitly account for an array of other factors affecting trade which have been identified in the literature: e.g., currency unions, colonial history, common language, common border, and ethnic networks. To the extent that these trade-drivers do not vary over time, these factors can be controlled for by means of country-pair specific fixedeffects (FE) estimations. ${ }^{7}$ Given the relatively short time span of our sample, most of these factors are indeed time invariant. Therefore, using FE - or more generally panel estimation techniques - has an additional advantage of being able to account for trade related factors that are difficult to quantify or even observe: e.g., institutional environment, information costs, and

\footnotetext{
${ }^{6}$ As previously noted, Baier and Bergstrand's (2007) data on FTA membership does not extend to 2005.

${ }^{7}$ More precisely, the fixed effects are exporter-importer specific, thus the fixed-effects can differ depending on the direction of trade regarding a country-pair.
} 
cultural proximity. This is important, since omitted variables can result in endogeneity problems and bias estimates (Jeffrey M. Wooldridge 2002: pp. 61-63). For instance, one might expect ISO 9000 diffusion to be supported by a nation's well-functioning institutions, but institutions are also likely to support trade (Anderson and Douglas Marcouiller 2002); hence, neglecting institutions in a gravity equation may lead to an upward bias in the estimated ISO 9000 coefficients. For example, Baier and Bergstrand (2007) also make great use of the country-pair specific effects in order to deal with FTA endogeneity when domestic policies are omitted variables. In short, country-pair fixed effects control for a large share of the possible sources of endogeneity by accounting for all observed and unobserved time invariant factors, thus it behooves us to also undertake these estimations.

Third, we also move beyond fixed effects by estimating a gravity equation controlling for "multilateral resistance terms", as derived in Anderson and van Wincoop's (2003) theoretical underpinning for the gravity equation. As shown in their model, the trade flows between any two countries are shaped by the trade costs between every possible country-pair due to general equilibrium effects. As a consequence, a proper gravity equation should be augmented by multilateral resistance terms to capture these effects. One means to follow through on that prescription in an empirical model is to introduce country-and-time-specific effects (Anderson and van Wincoop 2003; Robert Feenstra 2004). ${ }^{8}$ Although computationally simple, this method has the drawback that virtually all explanatory variables will be collinear with the country-andtime-specific effects, hence the coefficient estimates for these explanatory variables will not be identified. In particular, we will not be able to estimate the GDP, ISO 9000, and infrastructure coefficients for home and host nations in this treatment. Yet, the coefficient estimates for distance and home-host ISO interaction will be identified, as they vary across country-pairs and not only

\footnotetext{
${ }^{8}$ In a panel data model, one has to allow the country-specific effects to vary over time in order to capture varying multilateral price terms.
} 
countries. Accordingly, we will only be able to test for the presence of the common-language effect in the specification accounting for multilateral price terms. On the other hand, this test will be very powerful, as the country-and-time-specific effects account for all salient time-varying country characteristics - e.g., internet or mobile phone penetration - that might be omitted in the gravity equation.

\section{B. Instrumenting for ISO 9000 Diffusion with ISO 14000}

While the four estimations noted above are conscious of the potential for endogeneity (e.g., the equations involving country-pair fixed effects and multilateral resistance terms), it behooves us to more directly address the endogeneity issue due to its potential significance. Baier and Bergstrand's (2007) review of the endogeneity problem in the context of gravity equations highlights the general importance of endogeneity issues in empirical models of international trade. Yet as they point out, these efforts have largely concentrated on the endogeneity of income: "for about a decade, several researchers have acknowledged potential endogeneity bias, but only that created by GDPs as RHS variables" (Baier and Bergstrand 2007: p. 73). In particular, simultaneity of GDP could arise as a nation's GDP is a function of its exports via national income accounting. Empirical studies of trade, however, typically find an insignificant endogeneity bias for GDP coefficients (David Hummels and James Levinsohn 1995; Frankel and Wei 1997b). Frankel and Wei (1997a: p.79) summarize this point well when they state "evidently, the endogeneity of income makes little difference". The potential endogeneity of ISO 9000 diffusion, on the other hand, poses a more serious problem for our analysis.

The simultaneity issue is particularly germane to our context as standardization may indeed determine trade, yet trade may also determine standardization. As pointed out in the literature, 
higher trade levels indicate an economy's openness and can thus stimulate adoption of international standards (Casella 1996; Blind 2002). For instance, in an investigation of factors determining standardization in twenty industrial sectors for seven countries, Blind (2002) reports evidence supporting a positive relation between export-orientation (the ratio of exports to total production) and standardization-intensity (the stock of national and international standards). Recall also the work by Moenius (2004) supporting two-way causality between standards and trade. In our particular context, ISO 9000 adoption has been posited to be a function of trade volumes: for instance, Hanson (2005) notes that a virtual requirement for exporting to the $\mathrm{EU}$ is the obtainment of a CE marking - a mark that is based on the ISO 9000 system. Consequently, if one wants to elicit a robust relationship between ISO 9000 and trade, then one must account for possible simultaneity. Yet, the few empirical studies considering the impact of standards on trade do not tend to address the simultaneity issue.

Beyond the potential for simultaneity to create endogeneity bias, reside two additional common sources of endogeneity: omitted variables and measurement error (Wooldridge 2002: $\mathrm{p}$. 51). The previously noted country-pair specific fixed effects and multilateral resistance terms estimations go a long way to addressing concerns owing to omitted variables; thus, we largely follow here the approach by Baier and Bergstrand (2007) to address endogeneity issues via the strengths of a panel-data approach. With regard to measurement error as a source of endogeneity, it bares noting that our key explanatory variables regarding ISO 9000 penetration represent continuous constructs and not the dichotomous constructs that are often more subject to endogeneity concerns. As Baier and Bergstrand (2007: p. 80) state "the best method for eliminating this bias [measurement error] is construction of a continuous variable that would more accurately measure". 
While we carry these features - country-pair fixed effects and multilateral resistance terms - forward for our current empirical analysis, we can go deeper now in treating potential endogeneity by further addressing the issue of simultaneity between standards-intensity and trade flows, as this appears to be the most-relevant potential source of endogeneity in our gravity trade equations. In particular, we will improve upon the important panel-data enabled features of our analysis by layering on instrumental variable (IV) techniques. Hence, the combination of these approaches allows us to thoroughly control for endogeneity. While IV techniques have been previously employed in the trade literature to deal with endogeneity (e.g., Magee 2003; Baier and Bergstrand 2002), the impediment of identifying suitable instruments that are correlated with the explanatory variable but uncorrelated with the unobservables that impact bilateral trade has largely held up this approach (Baier and Bergstrand 2007). Yet we are fortunate to have an available and suitable instrument that allows tackling the simultaneity issue via the application of IV techniques in order to purify the ISO 9000 diffusion variables of the stochastic disturbance term and converge on a true coefficient estimate. In particular, we employ data on ISO 14000 diffusion to instrument for ISO 9000 diffusion.

ISO 14000 is a voluntary environmental standard covering management tools and systems aimed at monitoring and improving the environmental performance of a firm. What makes ISO 14000 such a good instrument for ISO 9000 are conditions of infrastructural convenience in terms of the common elements between the two standards. In fact, there exists empirical evidence that the number of ISO 14000 certifications is very positively related to the number of ISO 9000 certifications, consequently suggesting that the drivers behind the two have significant overlap (Charles J. Corbett and David A. Kirsch 2001; Gyula Vastag 2004). Further, Prakash and Potaski $(2006,2007)$ find that the number of national ISO 9000 certificates significantly impacts the number ISO 14000 certificates; but moreover, they also find that export orientation does not 
impact the number of ISO 14000 certificates in a nation. Hence, high levels of trade per se do not appear to significantly affect ISO 14000 certifications, thus corroborating our prior that ISO 14000 represents a good instrument.

\section{Discussion of the results}

Table 3 incorporates the econometric/modeling issues outlined above by reporting four different regression specifications. Regression 1 reports the results from the base gravity equation. Regression 2 reports the results for when the FTA variable is added as a regressor per the suggestion of Maskus, Wilson and Otsuki (2000). Regression 3 reports the results employing country-pair specific fixed-effects. Regression 4 reports the results employing multilateralresistance terms. These four different regression specifications will allow us to detect whether our main findings are generally robust. Furthermore - and in keeping with our efforts to layer IV techniques on top of panel-data features - Table 4 reports results where we replicate the four regression equations from Table 3 while employing IV estimation techniques for the three ISO variables: home-nation, host-nation, and home-host interaction.

The results reported in Tables 3 and 4 are generally consistent with the pre-existing empirical trade literature; though of course, the results do provide some new insights with respect to the impact of standardization on trade. The coefficient estimates for the main drivers behind the gravity forces - home-nation GDP, host-nation GDP, and distance - in the pooled regressions (Regressions' 1 and 2) correspond well to the standard results in the literature (e.g. Jeffrey A. Frankel and Shang-Jin Wei 1997b: Table 6.5a-b; Baier and Bergstrand 2007): i.e., the elasticity of exports with respect to GDP (both home and host) is close to 1, and the elasticity of exports 
with respect to distance is close to $-1 .{ }^{9}$ Additionally, the home-nation and host-nation GDP coefficient estimates in regression \#3 (the FE specification) are generally higher than the coefficient estimates in the pooled regressions (Regressions' 1 and 2) - a result which also conforms with previous work (e.g. Carrère 2006; Baier and Bergstrand 2007). Furthermore, the coefficient estimates on the population variables are mostly positive in the pooled regressions, and negative in the fixed-effects regression (Regression 3). While the coefficient estimates for population are generally expected to be positive, it is not uncommon to find the opposite sign in empirical estimations of gravity equations (e.g. Frankel and Wei 1997b: Tables 6.3 and 6.5a-b). ${ }^{10}$

The results regarding the infrastructure variables - which codetermine trade costs - also conform to expectation, as the coefficient estimates are positive and generally significant across the different regressions in Tables 3 and 4. Moreover, the magnitude of these effects is quite significant, as the elasticity of exports with respect to both home and host infrastructure indices varies between 0.08 and 0.34 in the pooled regressions (Regression 1 and 2) and between -0.01 and 0.07 in the fixed-effects regression (Regression 3) - comparable levels to the results reported in Carrère (2006). Also the impact of FTAs (Regression 2) appears to be positive with respect to exports, as expected, though this is only significant in the Table 3 regression.

Before turning to interpretations of our variables of principal interest - the trade effects of ISO 9000 penetration - we test for the endogeneity of international standardization. Recall that we have argued that endogeneity is a crucial analytical issue that has often been lacking in

\footnotetext{
${ }^{9}$ Note that the population variables in a gravity equation influence the coefficients on the GDP variables and should be interpreted together (see Jeffrey A. Frankel and Shang-Jin Wei 1997c: pages 57-59). For instance, the homenation GDP elasticity of 0.82 and the home-nation population elasticity of 0.36 in Regression 1 (Table 3 ) can be interpreted as home-nation GDP elasticity of 1.18 along with a home-nation GDP per capita elasticity of -0.36 . The two specifications (one with GDP and GDP per capita, and the other with GDP and population) are mathematically equivalent due to the use of logs.

${ }^{10}$ To be precise, Frankel and Wei (1997b) use the log of GDP per capita - not population variables - in their OLS regressions. Consequently, a positive coefficient on the GDP per capita variable is equivalent to a negative coefficient of the same magnitude on the population variable.
} 
previous trade studies. We can formally test for the presence of endogeneity by comparing the coefficient estimates from Table 3 (where the ISO variables act as their own instruments) with the coefficient estimates from Table 4 (where ISO 14000 adoption levels are used as instrumental variables for the ISO 9000 variables). ${ }^{11}$ Significant differences in the coefficient estimates between Table 3 and 4 are discernable, and Hausman specification tests reject [at the 1\% confidence level for Regressions' 1 and 3, the 5\% confidence level for Regression 4, and the $10 \%$ confidence level for Regression 2] the null hypothesis regarding the difference in coefficient estimates being non-systematic. Accordingly, Hausman tests confirm our prior that endogeneity matters empirically in the context of international standards and international trade.

In line with the presence of endogeneity, a visual comparison of Table 3 and 4 for the results concerning the three ISO variables indicates some significant differences concerning the impact of ISO 9000 diffusion on trade. First, the Table 3 results suggest a significant positive impact for home-nation ISO 9000 on exports. Yet interestingly, this positive push for homenation ISO diffusion is less evident (significant only in Regression 1 of Table 4) when we account for endogeneity in ISO 9000 adoption. While this result accords with the intuition that home-nation ISO diffusion is driven by the export orientation of an economy - e.g., export oriented nations tend to adopt ISO 9000 in order to conform with foreign buyer requirements the fact that the home-nation push is less significant once endogeneity is accounted for does imply the non-robustness of the enhanced-competitiveness channel captured by home-nation standardization. Second, the Table 3 results indicate that host-nation ISO 9000 diffusion yields some positive impact on exports (i.e., significant 'pull' effects are present in Regressions' 1 and 2), while the Table 4 results - where endogeneity is accounted for - generally indicate a negative

\footnotetext{
${ }^{11}$ The instrumental variables include home-nation adoption of ISO 14000, host-nation adoption of ISO 14000 and the interaction of the two. F-tests support the strength of ISO 14000 adoptions as instrumental variables at the $1 \%$ confidence level for all three ISO 9000 variables in all four regressions.
} 
impact on exports. Thus, the compliance-cost effect embedded in host-nation ISO 9000 diffusion becomes stronger/more-evident once the endogeneity of international standardization is taken into account. Third, the interaction of home-nation and host-nation standardization is generally stronger in the instrumented (Table 4) regressions as compared to the non-instrumented (Table 3 ) regressions; though, it is important to underscore that this interaction effect is positive and generally significant in both the instrumented and non-instrumented regressions-i.e., the common-language effect is the most robust channel via which standardization impacts international trade.

In short, ISO 9000 diffusion appears to be subject to significant endogeneity bias—a bias which needs to be accounted for in order to understand the relationship between international standardization and international trade. Accordingly, it behooves us to place more precedence on the coefficient estimates for the three ISO variables in Table 4 where instrumental variable techniques are employed to deal with the issue. Moreover, the Table 4 results yield some interesting implications with regard to the pre-existing literature on the relationship between international standards and international trade.

First, we find strong support for the common-language effect, as high levels of ISO 9000 adoption in both the home and host nation spur increased trade in the country-pair. While the ability of standards to reduce communication frictions between trading partners has been appreciated by many scholars (e.g., Casper and Hancké 1999; Bénézech et al. 2001; Blind, 2001), it has been difficult to empirically pin down these effects. Accordingly, common-language effects previously manifested via the home and host standardization measures. Capturing the commonlanguage effect via the interaction of home and host ISO penetration helps then disentangle these effects and suggests that the common-language effect is a very robust channel via which standardization affects trade. 
Second, the enhanced-competitiveness effect captured by home-nation standardization becomes less robust once the endogeneity of standardization is taken into account. Accordingly, this result potentially calls into question the literature (e.g., Swann, Temple and Shurmer 1996; Blind 2001, 2004; Ganslandt and Markusen 2001) which finds home-nation standardization to enhance the competitiveness of exports. That positive push for home-nation standardization found in previous work may actually just be an artifact of not fully controlling for the simultaneity between exports and standardization.

Third, the relative strength of the compliance-cost effect - which is embedded in hostnation standardization - once endogeneity is taken into account highlights the validity of the concerns by Maskus, Wilson and Otsuki (2000) and others regarding the ability of international standards to hinder trade between nations. Furthermore, our finding the trade-hindering elements to outweigh the trade-fostering elements of host-nation ISO 9000 standardization is particularly important. As previously noted, international standards have been generally found to promote trade more than national standards (Christopher Barrett and Yi-Nung Yang 2001; Blind 2001; Moenius 2004; Czubala, Shepherd and Wilson 2007; Shepherd 2007); and moreover, ISO 9000 has generally been considered to be the standard least subject to protectionist rationales (Blind 2004; Moenius 2006). Accordingly, if we are able to detect trade dampening effects due to the adoption of ISO 9000 standards, then it stands to reason that many other - if not all - standards will also involve some trade-hindering elements.

\section{Fortress Europe: ISO 9000 as a Device to Form an EU Standardization Union?}

The empirical results highlight the fact that the worldwide diffusion of ISO 9000 involves some trade-hindering elements; in particular, ISO 9000 adoption in host-nations can lead to the 
curtailment of imports from other nations. In light of the presence of this trade-dampening effect, the obvious next question is which nations might experience reduced exports due to the adoption of ISO standards in a host-nation environment? Akin to the concerns addressed by Frankel and Wei (1997a) regarding the European integration process being used to create a 'Fortress Europe', Hanson (2005) notes that the worldwide diffusion of standards has been considered by some as a means by the EU to protect domestic competitors and reduce imports. ${ }^{12}$ Gandal and Shy (2001) show that when conversion costs are relatively high and network effects are relatively minimal, then nations can increase welfare by creating a standardization union for the purpose of increasing trade for member countries at the expense of decreased trade from non-member countries. Two additional points highlight the potential for ISO 9000 to be employed by European nations as a barrier to market entry and a tariff on international trade.

First, ISO 9000 has been used in Europe as a standard against which to assess performance in government procurements and in setting minimum quality requirements for products that affect public safety. In particular, the 1992 Single Market Initiative initiated by the then European Community involved a significant public safety argument obliging firms to attain a uniquely designed EC Mark in order to gain access to certain European markets. ${ }^{13}$ Furthermore, the majority of the conformity assessment modules necessary for the CE marking program were based on the ISO 9000 series; i.e., the ISO 9000 quality control systems were the foundation for the CE mark - see Hanson (2005) for more details on CE Marking.

Second, it bears pointing out that the effort toward worldwide diffusion of international standards has been led by the EU and confirmed by the expansion of international institutions like

\footnotetext{
${ }^{12}$ It is healthy to point out here that Frankel and Wei (1997a) generally find - like most other studies - the EU integration process to be trade enhancing with respect to imports from non-EU nations (i.e., little trade-diversion takes place).

${ }^{13}$ Depending on the product category, the EC Mark had to be attained by some time between 1992 and 1995.
} 
the International Organization for Standardization (Casella 1996). Hanson (2005) points out that the EU has been far more unified in its participation in the International Organization for Standardization than have other nations: for instance, the EU embraces the International Organization for Standardization, receives one vote for every nation, and has strong representation (usually chairing) in the technical committees where the standards are designed and set; while the US is more interested in reciprocal recognition of national standards, receives only one vote as it is one nation, and often finds its comments ignored by the EU standard-setting process. It is no surprise then that standards developed by this process are considered by many to serve European interests (Hanson 2005).

Furthermore, quite a bit of policy-oriented literature exists concerning the impact of standard-counts and technical-regulations on intra-EU and extra-EU trade-flows - results which often conform to standardization-union properties by suggesting that EU standardization leads to trade-creation for intra-EU trade, and trade-diversion for EU imports from non-EU nations. In terms of EU standardization enhancing intra-EU trade: Brenton, Sheehy and Vancauteren (2001) find a substantial increase for Polish and Hungarian exports to EU-15 nations in industries where standards applied; and Vancauteren and Daniel Weiserbs (2005) support increased intra-EU trade from 1990 to 1998 due to efforts to harmonize European technical regulations. In terms of EU standardization decreasing EU imports from non-EU nations: Moenius (2006) finds EU importer standards to decrease agricultural imports from non-EU nations; Czubala, Sheperd and Wilson (2007) find that both the counts of ISO-harmonized and non-ISO-harmonized standards reduce EU imports from African nations, though ISO-harmonized standard counts are less trade restrictive; and Spencer Henson et al. (2000) found developing nations very constrained in their ability to export food to developed nations with standards being the highest barrier to enter the EU. Furthermore, Michael Gasiorek, Alasdair Smith and Anthony J. Venables (1992) and Jan 
Michalek et al. (2005) both found EU standardization to increase trade between EU members but impede imports from outside the EU.

In order to get a more complete picture of when additional home-nation and host-nation ISO 9000 adoptions enhance or hinder trade, Figure 1 uses the coefficient estimates for the three ISO variables from Regression 1 in Table 4 to illustrate the marginal effect on exports of additional ISO 9000 certification. ${ }^{14}$ In particular, the left panel shows the elasticity of exports with respect to home-nation adoptions, while the right panel shows the elasticity of exports with respect to host-nation adoptions. Notice that the marginal impact of additional home-nation ISO 9000 adoptions is always positive; i.e., the impact of additional home-nation standardization is positive for all the relevant levels of host-nation penetration. Yet this positive home-nation effect becomes larger at higher levels of host-nation standardization. In the right panel, however, the marginal impact of additional host-nation ISO 9000 adoptions only becomes positive once homenation diffusion levels are above 230 per million inhabitants: $(\log (230)=5.44)$. Given the distribution of national certification levels in our sample (Table 2), home-nation ISO adoption boosts exports to all nations in the sample, whereas host-nation certifications pull exports from some nations (the ISO-rich counties) but deter exports from other nations (the ISO-poor countries). Accordingly, host-nation certifications act to hinder trade from exporter nations that have not significantly adopted ISO 9000; i.e., the compliance-cost effect dominates the information effect when home-nation ISO levels fall below the critical threshold of 230 per million inhabitants. Table 1 illustrates which nations generally benefit and which suffer from worldwide diffusion of ISO 9000, as the ordering of the nations is by descending adoption levels, thus clearly distinguishing the cut-off level.

\footnotetext{
${ }^{14}$ Note that the maximum and minimum levels of ISO certifications in Figure 1 are chosen to reflect the distribution in the sample.
} 
The first point to note from Table 1 is that not one single developing nation is among the thirty-six nations with adoption levels above the cut-off level; therefore, none of the developing nations in our sample gain from ISO adoptions in other nations. In other words, developing nations never find the trade-enhancing information effects from host-nation standardization to outweigh the trade-hindering compliance-cost effects. This result is in line with the concerns by many scholars (e.g., Maskus, Wilson and Otsuki 2000; Blind 2001; Czubala, Shepherd and Wilson 2007) that firms from developing nations will be harmed by standardization, as they have no influence over the standardization process and find the compliance costs to be substantially high.

The second point to note from Table 1 is that the US (at 150 certificates per million inhabitants) also falls below the critical threshold for gaining from worldwide diffusion of standards. Hence, increased ISO 9000 standardization in other nations tends, in general, to reduce US exports to these nations. This result is in line with the thoughts of US-based critics who claimed that ISO 9000 was merely a barrier to market entry - a tariff on international trade - that represented a specific threat to US export interests (Hanson 2005).

The third point to note is that the nations above the critical threshold level are mostly European (only eight of the thirty-six are non-European), and only two European nations (Denmark and Lithuania) fall below the critical threshold level. In addition, Denmark and Lithuania have respective levels of 225 and 173 certificates per million inhabitants, thus they have the first and third highest adoption levels of all the nations falling below the critical threshold level - i.e., they just miss the cut-off. This result is in line with the idea that the worldwide diffusion of ISO 9000 standards sponsored by the International Organization for Standardization principally benefited European nations. It should be reiterated that eight nonEuropean developed nations (Singapore, Israel, Australia, New Zealand, Hong Kong, Japan, 
Canada, and Korea) have sufficiently adopted ISO 9000 at high levels, and accordingly gain from worldwide diffusion of standardization; i.e., they have essentially joined the ISO club.

In order to provide a more intuitive grasp on the economic significance of the above findings (based on the coefficient estimates from Table 4's Regression 1), we can take some representative nations (Germany, Mexico, UK, and US) and consider what potentially happens to trade between these nations at higher levels of ISO adoption. For instance, when Germany increases ISO 9000 adoptions by $10 \%$, Germany's exports to the UK, the US and Mexico respectively increase by $3.8 \%, 3.3 \%$ and $2.9 \%$. These simulations illustrate the above point regarding the impact of additional home-nation adoptions always being positive regardless of the different host-nation adoption levels. However, when we consider the impact on exports to Germany from the UK, the US and Mexico due to that same $10 \%$ increase in German standardization, then imports respectively change by $0.3 \%,-0.1 \%$ and $-0.5 \%$. These simulations illustrate the above points regarding European nations (e.g., the UK) gaining from the standardization process, while the US and developing nations like Mexico tend to lose exports due to worldwide standardization.

Furthermore, we can also get some perspective on how increased standardization outside of Europe can principally advantage European nations. For instance, a 10\% increase in ISO 9000 adoptions in the US respectively boosts exports to the UK, Germany and Mexico by $3.8 \%, 3.7 \%$ and 2.9\%; however, exports to the US from the UK, Germany and Mexico respectively change by $0.3 \%, 0.2 \%$ and $-0.5 \%$. Therefore, it is the ISO-rich European nations that principally gain from increased standardization in a nation like the US, while developing nations like Mexico find this diffusion of standards to be trade-hindering. 
Overall, our findings suggest that ISO 9000 spurs trade between ISO-rich nations and hampers trade between ISO-poor nations. The cut-off level illustrated in Figure 1 indicates that thirty-six nations in our sample benefit the most from ISO adoptions (i.e., the effective 'standardization union' members). Moreover, twenty-eight out of these thirty-six nations are European. Interestingly, the US and all developing nations do not belong to this ISO-rich set of nations. Furthermore, increased adoption within the standardization union strengthens intra-union trade, enhances union exports to the outside world, and protects the union from imports from the outside world. Accordingly, the above simulations illustrate that international standards can become de facto trade barriers even though they are not necessarily de jure trade barriers.

\section{Conclusion}

Motivated by the need to better understand the implications of worldwide diffusion of standardization on trade, this paper empirically assesses the link between international standards and international trade. Empirical scholarship on the standards/trade relationship has, however, been held up by three particular methodological challenges: measurement problems, varied effects, and endogeneity concerns. By investigating the impact of ISO 9000 - by far the most successful international standard implanted in the cross-national environment - on the bilateral trade flows between 91 nations over the 1995-2005 period, we are able to surmount some of these methodological challenges that have encumbered previous scholarship. First, we consider the penetration of ISO 9000 standards in a specific national environment, thus employing a continuous measure of standardization as opposed to the commonly-used inventory approach to capture standardization. Second, we allow ISO 9000 to manifest via multiple channels: an enhanced-competitiveness effect captured by home-nation standardization; a combined information/compliance-cost effect captured by host-nation standardization; and a common- 
language effect captured by the interaction of home and host standardization. Third, we employ panel data (fixed effects and multilateral resistance terms) and instrumental variable (IV) techniques in order to control for the potential endogeneity of ISO 9000.

The empirical results from our gravity trade equations yield three main findings concerning the standards/trade relationship. First, we find strong support for the commonlanguage aspect of ISO 9000, as combining high certification levels in both home and host nations robustly promotes trade. In other words, the positive effects of additional adoptions in one nation are enhanced by higher levels of ISO 9000 adoptions in the corresponding partner nation from a country-pair. Thus, ISO 9000 appears to lower information asymmetries between firms hailing from different nations and allows more efficient organization of vertical relations in a bilateral trade relationship. Second, the enhanced-competitiveness effect captured by homenation standardization becomes far less robust once the endogeneity of ISO 9000 standardization is more fully taken into account via instrumental variable techniques. This finding is important in that previous literature on the standards/trade relationship generally found the quality-signaling elements of standardization to involve a robust positive effect on home-nation exports. Yet this previous literature did not comprehensively tackle the endogeneity problem, thus our results cast some doubt on these previous findings and suggest that such trade-promotion effects may be due to untreated endogeneity. Third, we find the compliance-cost effect - which is embedded along with an information effect in host-nation standardization - to be relatively strong in the estimations employing instrumental variable techniques. This result confirms the concerns by many scholars that host-nation standardization can increase adaptation costs for home-nation exporter firms and lead to fewer host-nation imports.

In sum, the empirical results strongly support the common language aspects of ISO 9000, cast doubt on the robustness of the enhanced-competitiveness effect due to home-nation 
standardization, and exhibit evidence that ISO 9000 involves trade-hindering elements via hostnation adoption raising the compliance costs of exporters from other nations. It bears stating that ISO 9000 represents the quintessential international standard: by far the most successful implantation of any international standard, and generally considered to be the standard least subject to trade-dampening effects. Therefore, if we find ISO 9000 - the most international of standards - to have protectionist elements, then virtually all standards in existence will seemingly involve some trade-hindering effects. This point underscores the statement by Maskus, Wilson and Otsuki (2000: 6) that there is "no standards analogue to the claim that free trade in goods is globally optimal”.

The natural next question concerns which types of nations tend to benefit and which tend to lose from the worldwide diffusion of ISO 9000 standardization. In light of the significant role played by the EU in the International Organization for Standardization (where ISO 9000 was designed) and the fact that European nations obliged firms to certify with ISO 9000 in order to gain access to certain markets, the obvious initial suspicion is that ISO 9000 was used as a means to spur intra-European trade at the expense of imports from other nations. When we compare the empirical results with actual ISO 9000 adoption levels from our sample of nations, we find support for the "Fortress Europe" hypothesis. First, none of the developing nations in our sample manifest ISO 9000 adoption levels above the critical cut-off level indicating when a nation's exports are enhanced by ISO adoptions in other nations. In other words, developing nations never find the trade-promoting information effects to outweigh the trade-dampening compliance-cost effects from host-nation standardization. This result is consistent with the concerns by Maskus, Wilson and Otsuki (2000), Shepherd (2007) and others regarding firms in developing nations lacking the necessary information, technology, managerial capacity and finances to adopt production processes quickly in order to meet developed-world standards. 
In addition to the developing nations not exhibiting sufficient levels of ISO 9000 adoption, the US also falls below the critical cut-off level for gaining from worldwide diffusion of ISO standardization. Moreover, the nations above the critical threshold level are mostly European (28 out of 36), and only two European nations fall below the cut-off level. Accordingly, our results suggest that ISO 9000 represents a de facto trade barrier for the nations lagging behind in terms of adoption (overwhelmingly non-European), whereas ISO-rich nations (mostly European) benefit the most from the worldwide standardization process. Thus, the "Fortress Europe" hypothesis does find some empirical support here, as the worldwide diffusion of ISO 9000 standards appears to involve characteristics consistent with the fundamentals enhanced intra-union trade and union exports at the expense of imports from outside the union of a standardization union. 


\section{References}

Anderson, Shannon W., J. Daniel Daly, and Marilyn F. Johnson. (1995). "The Value of Management Control Systems: Evidence on the Market Reaction to ISO 9000 Quality Assurance Certificates.” University of Michigan Business School Working Paper 9501-16.

Anderson, Shannon W., J. Daniel Daly, and Marilyn F. Johnson. (1999). "Why Firms seek ISO 9000 Certification: Regulatory Compliance or Competitive Advantage?" Production and Operations Management, 8:1, 28-43.

Anderson, James E. (1979). “A Theoretical Foundation for the Gravity Equation.” American Economic Review, 69:1, 106-116.

Anderson, James E, and Douglas Marcouiller. (2002). "Insecurity and the Pattern of Trade: An empirical Investigation.” Review of Economics and Statistics, 84:2, 342-252.

Anderson, James E., and Eric van Wincoop. (2003). "Gravity with Gravitas: A Solution to the Border Puzzle.” American Economic Review.93:1, 170-192.

Baier, Scott L., and Jeffrey H. Bergstrand. (2002). "On the Endogeneity of International Trade Flows and Free Trade Agreements." mimeo.

Baier, Scott L., and Jeffrey H. Bergstrand. (2007). "Do Free Trade Agreements Actually Increase Members’ International Trade?” Journal of International Economics, 71:1, 72-95.

Baldwin, Richard. (2000). "Regulatory Protectionism, Developing Nations and a Two-tier World Trade System.” CEPR Discussion Paper 2574.

Barrett, Christopher B., and Yi-Nung Yang. (2001). "Rational incompatibility with international product standards" Journal of International Economics, 54:1, 171-191.

\section{Bénézech, Danièle, Gilles Lambert, Blandine Lanoux, Christophe Lerch, and Jocelyne} Loos-Baroin. (2001). "Completion of knowledge codification: an illustration through the ISO 9000 standards implementation process.” Research Policy, 30(9): 1395-1407. 
Bergstrand, Jeffrey H. (1985). "The Gravity Equation in International Trade: Some Microeconomic Foundations and Empirical Evidence." Review of Economics and Statistics, 67(3): 474-481.

Blind, Knut. (2001). "The Impact of Innovations and Standards on Trade of Measurement and Testing Products: Empirical Results of Switzerland's Bilateral Trade Flows with Germany, France and the UK." Information Economics and Policy, 13(4): 439-460.

Blind, Knut. (2002). "Driving Forces for Standardization at Development Organizations." Applied Economics, 34(16): 1985-1998.

Blind, Knut. (2004). The Economics of Standards: Theory, Evidence, Policy. Northampton, MA: Edward Elgar.

Boom, Anette. (1995). "Asymmetric International Minimum Quality Standards and Vertical Differentiation." Journal of Industrial Economics, 43(1): 101-119.

Brenton, Paul, John Sheehy, and Marc Vancauteren. (2001). "Technical Barriers to Trade in the European Union: Importance for Accession Countries." Journal of Common Market Studies, 39(2): 265-284.

Casella, Alessandra. (1996). "Free Trade and Evolving Standards." In Fair Trade and Harmonization: Prerequisites for Free Trade?, Vol. 1, ed. Bhagwati Jagdish and Robert Hudec, 119-156. Cambridge, MA: MIT Press.

Carrère, Cèline. (2006). "Revisiting the Effects of Regional Trade Agreements on Trade Flows with Proper Specification of the Gravity Model.” European Economic Review, 50(2): 223247.

Casper, Steve, and Bob Hancké. (1999). "Global Quality Norms with National Production Regimes: ISO 9000 Standards in the French and German Car Industries.” Organization Studies, 20(6): 961-985.

Clougherty, Joseph A., and Michal Grajek. (2008). “The Impact of ISO 9000 Diffusion on Trade and FDI: A New Institutional Analysis.” Journal of International Business Studies, 39(4): 613-633. 
Corbett, Charles J. and David A. Kirsch. (2001). "International Diffusion of ISO 14000 Certification." Production and Operations Management, 10(3): 327-342.

Czubala, Witold, Ben Shepherd, and John S. Wilson. (2007). "Help or Hindrance?: The Impact of Harmonized Standards on African Exports.” World Bank - Policy Research Working Paper 4400.

Deardorff, Alan V. (1998). "Determinants of Bilateral Trade: Does Gravity Work in a Neoclassical World?" In The regionalization of the world economy, ed. Jeffrey A. Frankel, 722. Chicago, IL: University of Chicago Press.

Deardorff, Alan V., and Robert M. Stern. (1998). Measurement of Nontariff Barriers. Ann Arbor:University of Michigan Press.

Delmas, Magali A. (2002). "The diffusion of environmental management standards in Europe and in the United States," Policy Sciences, 35: 91-119.

Dissanayaka, Sunil M., Mohan M. Kumarsawamy, Khalid Karim, and Marton Marosszeky. (2001). "Evaluating Outcomes from ISO 9000-certified Quality Systems of Hong Kong Constructors." Total Quality Management, 12(1): 29-40.

Eaton, Jonathan, and Samuel Kortum. (2002). "Technology, Geography, and Trade." Econometrica, 70(5): 1741-1779.

Feenstra, Robert. (2004). Advanced International Trade: Theory and Evidence. Princeton, NJ: Princeton University Press.

Frankel, Jeffrey A, and Shang-Jin Wei. (1997a). "Estimated Effects of Trading Blocs.” In Regional Trading Blocks in the World Economic System, ed. Frankel, Jeffrey A, 77-113. Washington, DC: Institute for International Economics.

Frankel, Jeffrey A, and Shang-Jin Wei. (1997b). "Extensions of the Empirical Analysis." In Regional Trading Blocks in the World Economic System, ed. Frankel, Jeffrey A, 115-148. Washington, DC: Institute for International Economics. 
Frankel, Jeffrey A, and Shang-Jin Wei. (1997c). “The Gravity Model of Bilateral Trade.” In Regional Trading Blocks in the World Economic System, ed. Frankel, Jeffrey A, 49-76. Washington, DC: Institute for International Economics.

Freund, Caroline L., and Diana Weinhold. (2004). "The effect of the Internet on international trade.", Journal of International Economics, 62: 171-189.

Gandal, Neil, and Oz Shy. (2001). "Standardization policy and international trade." Journal of International Economics, 53(2): 363-383.

Ganslandt, Mattias, and James R. Markusen. (2001). "National Standards and International Trade.” Research Institute of Industrial Economics Working Paper 547.

Gasiorek, Michael, Alasdair Smith and Anthony J. Venables. (1992). “1992: Trade and Welfare - A General Equilibrium Model.”, In Trade Flows and Trade Policy after 1992, ed. L.A. Winters. Cambridge, MA: Cambridge University Press.

Guler, Isin, Guillén, Mauro, F. and Macpherson, John Muir. (2002). "Global Competition, Institutions, and the Diffusion of ISO 9000 Quality Certificates.” Administrative Science Quarterly, 47: 207-232.

Hanson, David. (2005). CE Marking, Product Standards and World Trade. Northampton, MA: Edward Elgar.

Harrigan, James. (1993). “OECD Imports and Trade Barriers in 1983.” Journal of International Economics, 35: 91-111.

Helpman, Elhanan, and Paul Krugman. (1985). Market Structure and Foreign Trade. Cambridge, MA: MIT Press.

Henson, Spencer, Rupert Loader, Alan Swinbank, Maury Bredahl, and Nicole Lux. (2000). "Impact of Sanitary and Phytosanitary Measures on Developing Countries." Reading, UK: Center for Food Economics Research. http://www.cepea.esalq.usp.br/pdfs/134.pdf

Hudson, John, and Philip Jones. (2003). “International Trade in 'Quality Goods': Signalling Problems for Developing Countries.” Journal of International Development, 15: 999-1013. 
Hummels, David, and James Levinsohn. (1995). "Monopolistic Competition and International Trade: Reconsidering the Evidence.” Quarterly Journal of Economics, 110(3): 799-836.

ISO. (2002). The ISO Survey of ISO 9000 and ISO 14000 Certificates, Eleventh cycle - 2001, Geneva: ISO Central Secretariat.

ISO. (2005). ISO/TC 176 Business Plan N847. mimeograph.

ISO. (2006). The ISO Survey - 2005, Geneva: ISO Central Secretariat.

Laird, Sam, and Alexander Yeats. (1990). Quantitative Methods for Trade-Barrier Analysis. New York, NY: New York University Press.

Lee, Jong-Wha, and Phillip Swagel. (1997). "Trade barriers and trade flows across countries and industries." Review of Economics and Statistics, 79: 372-382.

Linnemann, Hans. (1966). An Econometric Study of International Trade Flows. Amsterdam: North-Holland.

Magee, Chris. (2003). "Endogenous Preferential Trade Agreements: An Empirical Analysis." Contributions to Economic Analysis and Policy, 2(1): Berkeley Electronic Press.

Maskus, Keith E., John S. Wilson, and Tsunehiro Otsuki. (2000). "Quantifying the Impact of Technical Barriers to Trade: A Framework for Analysis.” World Bank Policy Research Working Paper 2512.

Maskus, Keith E., Tsunehiro Otsuki, and John S. Wilson. (2004). "The Costs of Complying with Foreign Product Standards for Firms in Developing Countries: An Econometric Study." Institute of Behavioral Science Working Paper 2004-0004.

Matutes, Carmen, and Pierre Regibeau. (1996). "A Selective Review of the Economics of Standardization, Entry Deterrence, Technological Progress and International Competition.”, European Journal of Political Economy, 12: 183-209.

\section{Michalek, Jan, Jan Hagemejer, Victoria Roshal, Jacek Rothert, Alfred Tovias, Agnieszka} Pugacewicz, and Mark Vancauteren. (2005). "Comparative analysis of importance of technicial barriers to trade (TBT) for Central and Eastern European Countries and 
Mediterranean Partner Countries exports to the EU.” FEMISE Research Programme FEMISE Research No. 22-03.

Moenius, Johannes. (2004). "Information versus Product Adaptation: The Role of Standards in Trade.” Northwestern University, mimeograph.

Moenius, Johannes. (2006). “International Standardization as a Strategic Tool: Do National Standards Hinder or Promote Trade in Electrical Products.”, IEC - Geneva, Switzerland, mimeograph.

Prakash, Aseem, and Matthew Potoski. (2006). "Racing to the Bottom? Trade, Environmental Governance, and ISO 14001." American Journal of Political Science, 50(2): 350-364.

Prakash, Aseem, and Matthew Potoski. (2007). "Investing Up: FDI and the Cross-Country Diffusion of ISO 14001 Management Systems." International Studies Quarterly, 51(3): 723744.

Preeg, Ernest H. (1998). From Here to Free Trade. Chicago, IL: University of Chicago Press.

Rauch, James E. (1999). “Networks versus markets in international trade.” Journal of International Economics, 48(1): 7-35.

Rauch, James E., and Victor Trindade. (2002). "Ethnic Chinese Networks in International Trade." Review of Economics and Statistics, 84(1): 116-130.

Rose, Andrew X. (2004). “Do We Really Know That the WTO Increases Trade?” The American Economic Review, 94(1): 98-114.

Shepherd, Ben. (2007). "Product Standards, Harmonization, and Trade: Evidence from the Extensive Margin.” World Bank Policy Research Working Paper 4390.

Swann, Peter, Paul Temple, and Mark Shurmer. (1996). "Standards and Trade Performance: The UK Experience.” Economic Journal, 106(438): 1297-1313.

Terlaak, Ann, and Andrew A. King. (2006). "The effect of certification with the ISO 9000 quality management standard: A signaling approach." Journal of Economic Behavior and Organization, 60(4): 579-602. 
Terziovski, Milé, Damien Power, and Amrik S. Sohal. (2003). "The longitudinal effects of the ISO 9000 certification process on business performance." Production, Manufacturing and Logistics, 146: 580-595.

Tinbergen, Jan. (1962). Shaping the World Economy. New York: The Twentieth Century Fund.

Trefler, Daniel. (1993). "Trade liberalization and the theory of endogenous protection: an econometric study of U.S. import policy." Journal of Political Economy, 101(1): 138-160.

Vancauteren, Marc, and Daniel Weiserbs. (2005). "Intra-European trade of Manufacturing Goods: an Extension of the Gravity Model.” Université Catholique de Louvain - Discussion Paper 26.

Vastag, Gyula. (2004). "Revisiting ISO 14000 Diffusion: A New 'Look' at the Drivers of Certification." Production and Operations Management, 13(3): 260-267.

Wooldridge Jeffrey M. (2002). Econometric Analysis of Cross Section and Panel Data. Cambridge and London: the MIT Press. 
Table 1. List of countries in our sample and number of ISO 9000 certifications

\begin{tabular}{|c|c|c|c|c|c|}
\hline \multirow{2}{*}{ Country/Region } & \multicolumn{2}{|c|}{ ISO 9000 certifications } & \multirow{2}{*}{ Country/Region } & \multicolumn{2}{|c|}{ ISO 9000 certifications } \\
\hline & per mln inhab. & count & & per mln inhab. & count \\
\hline Italy & 1672.65 & 98028 & Denmark & 225.26 & 1219 \\
\hline Switzerland & 1669.20 & 12413 & Malaysia & 222.04 & 5695 \\
\hline Hungary & 1533.15 & 15464 & Lithuania & 173.39 & 591 \\
\hline Singapore & 1447.10 & 6282 & Mauritius & 163.28 & 202 \\
\hline Czech Republic & 1245.25 & 12743 & Turkey & 151.67 & 10929 \\
\hline Israel & 1106.07 & 7657 & United States & 149.31 & 44270 \\
\hline Spain & 1093.27 & 47445 & Bahrain & 149.01 & 107 \\
\hline Slovenia & 1057.24 & 2114 & Iceland & 148.27 & 43 \\
\hline Australia & 829.57 & 16922 & Uruguay & 144.90 & 478 \\
\hline UK & 757.36 & 45612 & Argentina & 143.42 & 5556 \\
\hline Malta & 750.93 & 302 & China & 110.21 & 143823 \\
\hline Cyprus & 700.71 & 530 & Colombia & 109.62 & 4926 \\
\hline Netherlands & 561.34 & 9160 & Oman & 106.90 & 267 \\
\hline Portugal & 551.78 & 5820 & Chile & 69.04 & 1124 \\
\hline Sweden & 525.82 & 4744 & Belarus & 67.41 & 658 \\
\hline New Zealand & 525.17 & 2170 & South Africa & 66.54 & 3119 \\
\hline Hong Kong & 506.37 & 3449 & Jordan & 54.33 & 293 \\
\hline Ireland & 494.34 & 2055 & Thailand & 51.30 & 3231 \\
\hline Germany & 482.81 & 39816 & Trinidad \& Tob. & 49.10 & 64 \\
\hline Belgium & 459.12 & 4810 & Brazil & 45.69 & 8533 \\
\hline Japan & 420.75 & 53771 & Iran & 44.74 & 3090 \\
\hline Austria & 409.19 & 3368 & Barbados & 41.11 & 11 \\
\hline Canada & 386.98 & 12503 & Tunisia & 37.99 & 380 \\
\hline Slovak Rep. & 380.73 & 2050 & Russian Feder. & 34.11 & 4883 \\
\hline Finland & 365.03 & 1914 & Costa Rica & 31.66 & 136 \\
\hline Estonia & 364.01 & 489 & St. Lucia & 30.34 & 4 \\
\hline France & 356.50 & 24441 & Mexico & 28.04 & 2890 \\
\hline Luxembourg & 324.06 & 147 & Panama & 25.07 & 80 \\
\hline Norway & 305.19 & 1410 & Paraguay & 24.92 & 146 \\
\hline Greece & 293.23 & 3255 & India & 22.52 & 24660 \\
\hline Korea & 290.59 & 14033 & Kazakhstan & 21.19 & 320 \\
\hline Bulgaria & 286.95 & 2220 & Indonesia & 18.45 & 4068 \\
\hline Croatia & 286.72 & 1273 & Egypt & 18.22 & 1326 \\
\hline Romania & 281.87 & 6097 & Philippines & 16.73 & 1414 \\
\hline Poland & 254.65 & 9718 & Venezuela & 16.48 & 437 \\
\hline Latvia & 244.29 & 561 & Belize & 13.71 & 3 \\
\hline
\end{tabular}

Notes: The ISO certifications as of December 2005

Sources: ISO (2006) and World Bank's WDI 
Table 1 (cont.). List of countries in our sample and number of ISO 9000 certifications

\begin{tabular}{|c|c|c|c|c|c|}
\hline \multirow{2}{*}{ Country/Region } & \multicolumn{2}{|c|}{ ISO 9000 certifications } & \multirow{2}{*}{ Country/Region } & \multicolumn{2}{|c|}{ ISO 9000 certifications } \\
\hline & per mln inhab. & count & & per mln inhab. & count \\
\hline Morocco & 13.40 & 403 & Bangladesh & 3.72 & 570 \\
\hline Pakistan & 12.93 & 2013 & Senegal & 3.48 & 40 \\
\hline Botswana & 12.53 & 22 & Honduras & 3.37 & 22 \\
\hline Sri Lanka & 12.46 & 244 & Guatemala & 2.44 & 30 \\
\hline Guyana & 12.17 & 8 & Dominican Rep. & 2.43 & 22 \\
\hline Bolivia & 11.44 & 104 & Zambia & 1.92 & 21 \\
\hline Namibia & 11.39 & 22 & Sudan & 0.89 & 32 \\
\hline Ecuador & 10.80 & 140 & Cameroon & 0.79 & 13 \\
\hline Zimbabwe & 9.91 & 129 & Malawi & 0.68 & 8 \\
\hline Peru & 7.11 & 193 & & & \\
\hline
\end{tabular}

Notes: The ISO certifications as of December 2005

Sources: ISO (2006) and World Bank's WDI 
Table 2. Variable description and summary statistics

\begin{tabular}{|c|c|c|c|c|c|c|}
\hline Variable & Definition and Source & Obs. & Mean & Std. dev. & Min & Max \\
\hline $\operatorname{Exp}_{i j t}$ & $\begin{array}{l}\text { Exports from country i to country j } \\
\text { in billions of } 2000 \text { US\$ (UN's } \\
\text { Comtrade) }\end{array}$ & 17085 & 7.559 & 49.04 & 0.000 & 2399 \\
\hline$G D P_{i t}$ & $\begin{array}{l}\text { GDP of country } i \text { in billions of } 2000 \\
\text { US\$ (World Bank's WDI) }\end{array}$ & 17085 & 356.45 & 1073.10 & 0.57 & 9760 \\
\hline$G D P_{j t}$ & $\begin{array}{l}\text { GDP of country } j \text { in billions of } 2000 \\
\text { US\$ (World Bank's WDI) }\end{array}$ & 17085 & 345.42 & 1038.42 & 0.57 & 9760 \\
\hline$P O P_{i t}$ & $\begin{array}{l}\text { Population of country } i \text { in millions } \\
\text { (World Bank's WDI) }\end{array}$ & 17085 & 58.67 & 173.83 & 0.14 & 1263 \\
\hline$P O P_{j t}$ & $\begin{array}{l}\text { Population of country } j \text { in millions } \\
\text { (World Bank's WDI) }\end{array}$ & 17085 & 57.18 & 167.16 & 0.14 & 1263 \\
\hline Dist $_{i j}$ & $\begin{array}{l}\text { Great-circle distance between } \\
\text { country } i \text { and country } j \text { (Rose 2004) }\end{array}$ & 17085 & 4639.9 & 2890.6 & 62.3 & 12351.2 \\
\hline ISO9000 & $\begin{array}{l}\text { Number of ISO } 9000 \text { certifications } \\
\text { in country } i \text { per mln. inhabitants } \\
\text { (ISO 2002, 2006) }\end{array}$ & 17085 & 214.97 & 327.74 & 0.008 & 1672.7 \\
\hline$I S O 9000_{j t}$ & $\begin{array}{l}\text { Number of ISO } 9000 \text { certifications } \\
\text { in country } j \text { per mln. inhabitants } \\
\text { (ISO 2002, 2006) }\end{array}$ & 17085 & 202.89 & 323.61 & 0.008 & 1672.7 \\
\hline Infr $r_{i t}$ & $\begin{array}{l}\text { Index of country } i \text { 's infrastructure } \\
\text { (World Bank's WDI) }\end{array}$ & 17085 & 0.622 & 0.697 & 0.006 & 5.40 \\
\hline $\operatorname{Inf} r_{j t}$ & $\begin{array}{l}\text { Index of country } j \text { 's infrastructure } \\
\text { (World Bank's WDI) }\end{array}$ & 17085 & 0.610 & 0.709 & 0.006 & 5.40 \\
\hline$F T A_{i j t}$ & $\begin{array}{l}\text { Existence of free trade agreement } \\
\text { between home and host nation } \\
\text { (Baier \& Bergstrand } 2007 \text { and } \\
\text { sources listed there) }\end{array}$ & 6038 & 0.119 & 0.324 & 0 & 1 \\
\hline$I_{S O 14000_{i t}}$ & $\begin{array}{l}\text { Number of ISO } 14000 \text { certifications } \\
\text { in country } i \text { per mln. inhabitants } \\
\text { (ISO 2002, 2006) }\end{array}$ & 16938 & 22.25 & 48.67 & 0.001 & 408.1 \\
\hline$I S O 14000_{j t}$ & $\begin{array}{l}\text { Number of ISO } 14000 \text { certifications } \\
\text { in country } i \text { per mln. inhabitants } \\
\text { (ISO 2002, 2006) }\end{array}$ & 16917 & 21.39 & 48.09 & 0.001 & 408.1 \\
\hline
\end{tabular}


Table 3. Gravity equation for exports: OLS Estimation results

Dependent variable: $\ln$ Exports $_{\mathrm{ijt}}$

\begin{tabular}{|c|c|c|c|c|}
\hline Independent variables & (1) & (2) & (3) & (4) \\
\hline \multicolumn{5}{|l|}{ Base gravity: } \\
\hline \multirow[t]{2}{*}{ Home-Nation GDP } & $0.82 * * *$ & $0.68 * * *$ & $1.79 * * *$ & \\
\hline & $(0.03)$ & $(0.04)$ & $(0.16)$ & \\
\hline \multirow[t]{2}{*}{ Host-Nation $G D P_{j t}$} & $0.81 * * *$ & $0.77 * * *$ & $1.82 * * *$ & \\
\hline & $(0.03)$ & $(0.05)$ & $(0.13)$ & \\
\hline \multirow[t]{2}{*}{ Home-Nation POP ${ }_{i t}$} & $0.36 * * *$ & $0.45 * * *$ & $-1.48 * * *$ & \\
\hline & $(0.03)$ & $(0.04)$ & $(0.29)$ & \\
\hline \multirow[t]{2}{*}{ Host-Nation POP ${ }_{j t}$} & $0.13 * * *$ & $0.11 * *$ & $-0.89 * * *$ & \\
\hline & $(0.03)$ & $(0.05)$ & $(0.29)$ & \\
\hline \multirow[t]{2}{*}{ Dist $_{i j t}$} & $-1.29 * * *$ & $-1.12 * * *$ & & $-1.71 * * *$ \\
\hline & $(0.02)$ & $(0.04)$ & & $(0.03)$ \\
\hline \multicolumn{5}{|l|}{ ISO 9000: } \\
\hline \multirow[t]{2}{*}{ Home-Nation ISO9000 } & $0.21 * * *$ & $0.27 * * *$ & $0.07 * * *$ & \\
\hline & $(0.02)$ & $(0.03)$ & $(0.01)$ & \\
\hline Host-Nation ISO9000 $j t$ & $\begin{array}{l}0.03^{*} \\
(0.02)\end{array}$ & $\begin{array}{l}0.06^{* *} \\
(0.03)\end{array}$ & $\begin{array}{l}0.01 \\
(0.01)\end{array}$ & \\
\hline \multirow[t]{2}{*}{$I_{S O 9000_{i t}} * I_{S O 9000_{j t}}$} & $0.01 * * *$ & $0.01 * * *$ & 0.001 & 0.001 \\
\hline & $(0.002)$ & $(0.003)$ & $(0.002)$ & $(0.003)$ \\
\hline \multicolumn{5}{|l|}{ Other controls: } \\
\hline \multirow[t]{2}{*}{ Home-Nation Infr $r_{i t}$} & $0.15 * * *$ & $0.08 *$ & $0.04 *$ & \\
\hline & $(0.03)$ & $(0.04)$ & $(0.02)$ & \\
\hline \multirow[t]{2}{*}{ Host-Nation Infr $r_{j t}$} & $0.14 * * *$ & 0.08 & -0.01 & \\
\hline & $(0.03)$ & $(0.05)$ & $(0.02)$ & \\
\hline \multirow[t]{2}{*}{$F T A_{i j t}$} & & $0.22 * *$ & & \\
\hline & & $(0.09)$ & & \\
\hline Year dummy & Yes & Yes & Yes & Yes \\
\hline Country-pair fixed effects & - & - & Yes & - \\
\hline $\begin{array}{l}\text { Multilateral resistance } \\
\text { terms }\end{array}$ & - & - & - & Yes \\
\hline Observations & 17085 & 6038 & 16285 & 17546 \\
\hline
\end{tabular}

Notes: All variables except dummy variables are in logarithms.

${ }^{* * *}$ denotes significance at $1 \%$ level, ${ }^{* *}$ at $5 \%$ level, ${ }^{*}$ at $10 \%$ level; cluster-robust standard errors in parentheses. 
Table 4. Gravity equation for exports: IV Estimation results

Dependent variable: $\ln$ Exports $_{\mathrm{ijt}}$

\begin{tabular}{|c|c|c|c|c|}
\hline Independent variables & (1) & (2) & (3) & (4) \\
\hline \multicolumn{5}{|l|}{ Base gravity: } \\
\hline \multirow[t]{2}{*}{ Home-Nation GDP } & $0.79 * * *$ & $0.76^{*}$ & $2.38 * * *$ & \\
\hline & $(0.07)$ & $(0.45)$ & $(0.41)$ & \\
\hline \multirow[t]{2}{*}{ Host-Nation $G D P_{j t}$} & $0.94 * * *$ & $1.37 * * *$ & $1.14 * * *$ & \\
\hline & $(0.06)$ & $(0.32)$ & $(0.40)$ & \\
\hline \multirow[t]{2}{*}{ Home-Nation POP ${ }_{i t}$} & $0.38 * * *$ & 0.36 & $-1.35^{* *}$ & \\
\hline & $(0.06)$ & $(0.46)$ & $(0.59)$ & \\
\hline \multirow[t]{2}{*}{ Host-Nation POP ${ }_{j t}$} & 0.01 & -0.51 & 0.37 & \\
\hline & $(0.06)$ & $(0.33)$ & $(0.79)$ & \\
\hline \multirow[t]{2}{*}{$D_{i s t} t_{i j t}$} & $-1.26^{* * *}$ & $-1.14 * * *$ & & $-1.69 * * *$ \\
\hline & $(0.02)$ & $(0.04)$ & & $(0.03)$ \\
\hline \multicolumn{5}{|l|}{ ISO 9000: } \\
\hline \multirow[t]{2}{*}{ Home-Nation ISO9000 } & $0.20 * * *$ & 0.17 & -0.32 & \\
\hline & $(0.07)$ & $(0.41)$ & $(0.23)$ & \\
\hline \multirow[t]{2}{*}{ Host-Nation ISO9000 ${ }_{j t}$} & $-0.15 * * *$ & $-0.45^{*}$ & 0.29 & \\
\hline & $(0.05)$ & $(0.26)$ & $(0.18)$ & \\
\hline \multirow[t]{2}{*}{$I_{S O 9000_{i t}} * \operatorname{ISO}{ }^{2} 000_{j t}$} & $0.03 * * *$ & $0.02 * * *$ & $0.02 * *$ & $0.01 *$ \\
\hline & $(0.004)$ & $(0.01)$ & $(0.01)$ & $(0.01)$ \\
\hline \multicolumn{5}{|l|}{ Other controls: } \\
\hline \multirow[t]{2}{*}{ Home-Nation Infr $r_{i t}$} & $0.10^{*}$ & 0.11 & 0.07 & \\
\hline & $(0.05)$ & $(0.31)$ & $(0.04)$ & \\
\hline \multirow[t]{2}{*}{ Host-Nation Infr $r_{j t}$} & $0.20 * * *$ & $0.34 * *$ & 0.02 & \\
\hline & $(0.04)$ & $(0.15)$ & $(0.03)$ & \\
\hline \multirow[t]{2}{*}{$F T A_{i j t}$} & & 0.08 & & \\
\hline & & $(0.10)$ & & \\
\hline Year dummy & Yes & Yes & Yes & Yes \\
\hline Country-pair fixed effects & - & - & Yes & - \\
\hline $\begin{array}{l}\text { Multilateral resistance } \\
\text { terms }\end{array}$ & - & - & - & Yes \\
\hline Observations & 16771 & 6038 & 15917 & 17223 \\
\hline
\end{tabular}

Notes: All variables except dummy variables are in logarithms.

${ }^{* * *}$ denotes significance at $1 \%$ level, ${ }^{* *}$ at $5 \%$ level, ${ }^{*}$ at $10 \%$ level; cluster-robust standard errors in parentheses. 
Figure 1. Elasticity of exports based on results from Regression 1 in Table 4

a) with respect to home-nation adoption

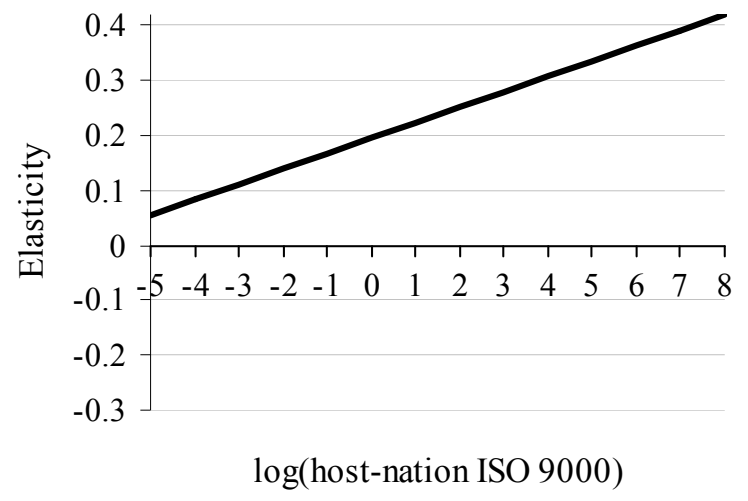

b) with respect to host-nation adoption

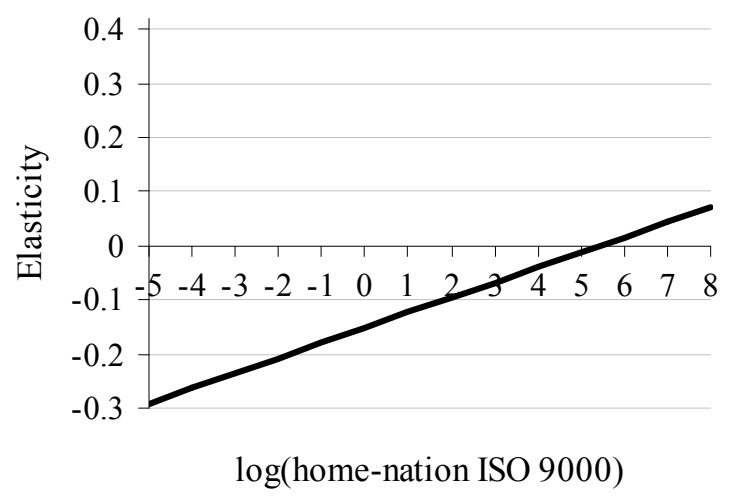






\section{Recent ESMT Working Papers}

\begin{tabular}{|c|c|c|}
\hline & $\begin{array}{l}\text { ESMT } \\
\text { No. }\end{array}$ & $\begin{array}{l}\text { Competence } \\
\text { Center }\end{array}$ \\
\hline $\begin{array}{l}\text { ISO 9000: New Form of Protectionism or Common Language in } \\
\text { International Trade? }\end{array}$ & 09-006 & $\begin{array}{l}\text { European } \\
\text { Competitiveness }\end{array}$ \\
\hline \multicolumn{3}{|l|}{$\begin{array}{l}\text { Joseph A. Clougherty, University of Illinois at Urbana-Champaign, WZB-Berlin, } \\
\text { and CEPR-London } \\
\text { Michat Grajek, ESMT }\end{array}$} \\
\hline $\begin{array}{l}\text { Demography vs. Context: A Cross-Country Survey of the Willingness to Rely } \\
\text { on Trust in Business Partnerships }\end{array}$ & 09-005 & $\begin{array}{l}\text { Management } \\
\text { of }\end{array}$ \\
\hline $\begin{array}{l}\text { Francis Bidault, ESMT } \\
\text { José R. de la Torre, Florida International University } \\
\text { Stelios H. Zanakis, Florida International University }\end{array}$ & & Technology \\
\hline $\begin{array}{l}\text { Regulation and Investment in Network Industries: Evidence from European } \\
\text { Telecoms }\end{array}$ & 09-004 & $\begin{array}{l}\text { European } \\
\text { Competitiveness }\end{array}$ \\
\hline \multicolumn{3}{|l|}{$\begin{array}{l}\text { Michat Grajek, ESMT } \\
\text { Lars-Hendrik Röller, ESMT }\end{array}$} \\
\hline $\begin{array}{l}\text { Access Regulation and Investment in Next Generation Networks: A Ranking } \\
\text { of Regulatory Regimes }\end{array}$ & 09-003 & $\begin{array}{c}\text { European } \\
\text { Competitiveness }\end{array}$ \\
\hline \multicolumn{3}{|l|}{$\begin{array}{l}\text { Rainer Nitsche, ESMT } \\
\text { Lars Wiethaus, ESMT }\end{array}$} \\
\hline $\begin{array}{l}\text { The Effect of Adversity on Process Innovations and Managerial Incentives } \\
\text { Benoit Dostie, HEC Montréal } \\
\text { Rajshri Jayaraman, ESMT }\end{array}$ & 09-002 & $\begin{array}{l}\text { Management } \\
\text { of } \\
\text { Technology }\end{array}$ \\
\hline $\begin{array}{l}\text { An Empirical Approach to Understanding Privacy Concerns } \\
\text { Luc Wathieu, ESMT } \\
\text { Allan Friedman, John F. Kennedy School, Harvard University }\end{array}$ & 09-001 & $\begin{array}{l}\text { Management } \\
\text { of } \\
\text { Technology }\end{array}$ \\
\hline $\begin{array}{l}\text { Cosmopolitanism, Assignment Duration, and Expatriate Adjustment: The } \\
\text { Trade-Off between Well-Being and Performance }\end{array}$ & 08-011 & Leadership \\
\hline \multicolumn{3}{|l|}{$\begin{array}{l}\text { Luc Wathieu, ESMT } \\
\text { Amir Grinstein, Guilford Glazer School of Business and Management, Ben } \\
\text { Gurion University of the Negev }\end{array}$} \\
\hline $\begin{array}{l}\text { Trust and Creativity: Identifying the Role of Trust in Creativity-oriented } \\
\text { J oint-developments }\end{array}$ & 08-010 & $\begin{array}{l}\text { Management } \\
\text { and }\end{array}$ \\
\hline $\begin{array}{l}\text { Francis Bidault, ESMT } \\
\text { Alessio Castello, Georgia Tech France }\end{array}$ & & Technology \\
\hline Career Entrepreneurship & 08-009 & Leadership \\
\hline \multicolumn{3}{|l|}{$\begin{array}{l}\text { Konstantin Korotov, ESMT } \\
\text { Svetlana Khapova, ESMT Visiting Professor and Associate Professor at VU } \\
\text { University Amsterdam } \\
\text { Michael B. Arthur, Sawyer School of Management, Suffolk University }\end{array}$} \\
\hline $\begin{array}{l}\text { Technology Commercialization Strategy in a Dynamic Context: } \\
\text { Complementary Assets, Hybrid Contracts, and Experiential Learning } \\
\text { Simon Wakeman, ESMT }\end{array}$ & $\begin{array}{c}\text { 08-008 } \\
\text { (R1) }\end{array}$ & $\begin{array}{l}\text { Management } \\
\text { and } \\
\text { Technology }\end{array}$ \\
\hline
\end{tabular}




\section{ESMT}

European School of Management and Technology $\mathrm{GmbH}$

Schlossplatz 1

10178 Berlin

Germany

Phone: +49 (0)30212 31-1279

www.esmt.org 